\section{The Central Register}

IN reply to a question asked by Sir Herbert Williams, the Minister of Labour and National Service stated in the House of Commons on December 11 that as soon as the necessary arrangements can be made, the present Central and Supplementary Registers are to be merged in a new Appointments Department of the Ministry of Labour and National Service. This new department will deal with persons possessing specified administrative, managerial, professional, or technical qualifications and with others who, though not possessing specific qualifications, have a normal salary in excess of $£ 420$ per annum. It will operate through its staff at headquarters or through staff under the control of the Regional Controllers, according to the nature of the vacancies for candidates. It will maintain a separate register of persons within its scope who are known to be seeking an engagement and will endeavour to find suitable employment for such persons in some form of national service. The provincial organization of the department will be closely associated with the new district man-power boards.

\section{Gas-producer Poisoning in Sweden}

According to the October issue of the AngloSwedish Review, medicine and technology in Sweden are collaborating in the problem of poisoning from gas-producers, with the result of the establishment of the first clinic in the north at the Sabbatsberg Hospital in Stockholm. The work is being conducted on the following lines: (1) Examination in the laboratory of specimens of blood for carbon monoxide content. Up to the present 4,300 analyses have been made. (2) A clinic of ten beds has been set up and an out-patient department where over 700 cases have been examined. (3) Physiological examinations are being made to discover the most suitable form of treatment and the proportion of chronic cases. (4) Examination of the cerebrospinal fluid in patients who have died from asphyxia is being carried out. The experiments are being made on human volunteers and on porpoises and rats.

\section{Use of Pitch as Fuel}

Ir is well known that modern life in peace and especially in war depends on fuel in liquid form. While consumption of the lighter and more volatile fuels in internal combustion engines is more apparent to the layman, there is a large consumption of heavier fuel oils consumed for industrial furnaces and on board ships. In peace-time practically all the supply of such heavy oils used in Great Britain were imported and a relatively low price was efficiently maintained. Indeed, industry was furnished with a fuel often superior in quality to what was essential to the purpose in question. The reduction in available supplies of imported oil has compelled the use of heavier and lower grade petroleum oils and indigenous materials such as cresote and pitch-creosote blends.

An interesting development is the use of coal tar pitch itself, both solid-as pulverized pitch-and liquid-as molten pitch. Such materials find their application particularly where consumption is large and continuous-for example, in steam boilers and large furnaces. The fuel has certain attractive properties-low sulphur content, freedom from ash and water, uniformity in quality and calorific value. For use it must be heated to $200^{\circ} \mathrm{C}$. and conveyed in pipes to the furnaces at this temperature. This has produced unusual engineering problems, the solution of which has required great skill, because the consequences of failure are serious, if ever the pitch solidifies in the mains. The plant used for this purpose was described at a meeting of the Institute of Fuel in London on October 30. This is a valuable technical achievement, because production of pitch has for years exceeded demand and there is in stock a very large quantity which can replace much petroleum oil formerly employed.

\section{Standardization in the Electrical Industry}

A Thoughtful address was delivered on October 27 by Mr. H. G. Taylor, chairman of the Liverpool Centre of the Institution of Electrical Engineers, on "Co-ordination and Standardization". He regards co-ordination as the best means of arriving at standardization. $\mathrm{He}$ said it would be disastrous if the end of the War found engineers unprepareu to face the problems of peace in a changed world. Immediately after the War of 1914-18, a major happening in the history of the electrical supply industry in Great Britain was the appointment by the Board of Trade of the Electricity Commissioners as a technical body under the chairmanship of Sir John Snell. As a result of their investigations and in conjunction with the Weir Committee, the Central Electricity Board was established in 1926, its function being to supply electricity in bulk to various distributors and concurrently to increase the availability of supply. This entailed co-ordinating the existing supply authorities, their personnel and plant, while the question of interconnexion of plant involved standardization of frequency, the necessity of which Sir John Snell foresaw, and powers to enforce a national standard of 50 cycles were consequently included in the Act of 1926. As a theory, standardization in electrical engineering is almost as old as the science itself, but its application in Great Britain has lagged too far behind technical progress to maintain a healthy condition in the industry, the development of the heavier engineering commodities having continued, for the most part, on individual lines.

The recognized centre now for dealing with standardization is the British Standards Institution, which now has more than a thousand committees, with about six thousand professional men who have given their time freely to this national work. It is an independent body in close touch with industrial requirements and modern technical knowledge, with the fullest Government support but free from Government control. It co-operates with the central standardization bodies in various parts of the British Commonwealth of Nations, and participates, directly or indirectly, in the work of international standardization. 
After the War, we must produce for export not the apparatus which other countries rightly wished to manufacture themselves, but commodities in which we have the technical ability to make ourselves supreme. By complete co-ordination of industrial organizations and research establishments electrical engineers can assist very materially, and the adoption of international standards must be considered. Mr. Taylor suggested uniformity of design for utility electrical products in common use both in the industrial and domestic fields. Such a standard, to be effective, would need to have behind it the authority of the British Standards Institution, and its adoption might even need legislative action. Manufacturers would be encouraged to adopt these standard commodities as their first line of production, and in consequence they would ultimately replace the many specialized products now on the market.

\section{Arterial Road Lighting}

THE arterial road connecting Toronto and Niagara Falls, known as Queen Elizabeth Way, is lighted by incandescent lamps in parallel over its whole length of 70 miles. Already the lighting installation enjoys the distinction of being the longest in the world, and no doubt it will be continued on the proposed 20mile extension of the highway to Fort Erie, making a total of 90 miles. In planning the installation provision was made for maximum silhouetting of obstacles. The Way consists of dual concrete tracks 20-23 ft. in width with an intervening strip of grass 28-30 ft. wide; the standard equipment comprises wooden poles, along the centre line of the grass, with welded cross-arms overhanging each traffic lane to the extent of $3 \mathrm{ft}$. The availability of cheap electric power from existing rural circuits operated by the Hydro-Electric Power Commission of Ontario seems to have been a determining factor in the adoption of incandescent lighting and parallel distribution. Sodium lamps are used to mark intersections. Distribution transformers of $15-\mathrm{kva}$. capacity feed the $115-\mathrm{v}$. lighting cables from the $2,300 \cdot v$. rural distribution network. The lamps are of 6,000 lumens, 400 watts, spaced $200 \mathrm{ft}$. apart, and maintenance is by group replacement twice a year. Operating experience and costs from this installation should be of material assistance in planning the general lighting of arterial roads.

\section{Discovery of Smithfield Industries in Kenya}

The September-October number of Mun contains a letter which is of distinct importance to those who concern themselves with the problems of Stone Age Africa. It would seem certain that Archdeacon Owen has discovered in a rock-shelter in Kenya an early Smithfield industry, and that Prof. van Riet Lowe has agreed with his interpretation. Smithfield industries occur over large parts of South Africa, especially in the Free State, the material used for their manufacture being usually the local indurated shale which chips well. Scrapers, awls, beads, and occasionally a little pottery have been found. The range in time of the culture extends backwards from modern days to an unknown, but probably fairly remote, period as the later Smithfield industries show differences when compared with the earlier ones. Thus the plano-convex knife is an early tool type and does not recur in the more recent finds, while pottery seems to be absent from the earlier ones. In South Africa, too, there are regional differences in the industries which add to their complexity. But the main great problem has always been as to whether the Smithfield culture as a whole was an autochthonous growth in South Africa itself, engendered perhaps by culturecontacts; or whether it was not rather introduced into the subcontinent by migrations from the rorth. Archdeacon Owen's new discovery of Early Smithfield material-considered in fact to be even some. what older than the Early Smithfield of South Africa -in Kenya would suggest that the latter hypothesis is the correct one.

\section{Folk-lore of Alcoholism}

IN a paper on this subject (Brit. J. Inebriety, JulyOctober), Dr. J. D. Rolleston remarks that with the exception of Hovorka and Kronfeld's great work on comparative folk medicine no writers have dwelt at length on folk-lore in relation to alcoholism. He has therefore collected the folk-lore of this condition, as he has recently done in the case of general medicine, dermatology and pulmonary tuberculosis. His paper deals with the nomenclature, popular phraseology, superstitions and leecheraft connected with alcoholism and alcohol, the term 'leechcraft' being that commonly employed in the language of folk-lore to indicate popular methods of prevention and treatment. In a previous paper on "Alcoholism in Classical Antiquity" (Brit. J. Inebriety, 24, 101; 1927) he directed attention to the numerous synonyms for inebriated or bibulous persons, both in Greek and Latin, as well as in English, which contained about seventy such terms, only a minority of which could be called slang, whereas there are more than 280 slang synonyms for the word 'drink', 160 for the verb 'to drink', and 150 for various forms of intoxication. Popular interest in the consumption of alcohol, especially in excess, was further demonstrated by the great variety of similes connected with the subject. After dealing with the superstitions and popular errors connected with alcohol and alcoholism, which are legion, Dr. Rolleston discusses the popular methods of prevention and cure for inebriety, which he classifies under the headings of animal remedies, including coprotherapy, plant remedies, of which a large proportion are mentioned by Pliny, mineral remedies, invocation of patron saints and water.

\section{Tuberculosis and War}

According to an editorial in the August issue of the Statistical Bulletin of New York, tuberculosis is already on the increase in other countries than the United States, although the evidence is based only on provisional or fragmentary data. In England and Wales the death-rate among male civilians rose slightly in 1939 and in 1940 in both sexes. For males the death-rate from tuberculosis rose 13 per cent 